\title{
HUBUNGAN SANITASI ASRAMA DAN PERSONAL HYGIENE SANTRI DENGAN KEJADIAN SCABIES DI PONDOK PESANTREN AL IKHSAN DESA BEJI KECAMATAN KEDUNGBANTENG KABUPATEN BANYUMAS TAHUN 2018
}

\author{
Tri Nova Rofifah ${ }^{1)}$, Lagiono ${ }^{2)}$, Budi Utomo ${ }^{3)}$ \\ Jurusan Kesehata Lingkungan, Politeknik Kesehatan Kemenkes Semarang \\ Jl. Raya Baturaden KM 12 Purwkerto, Indonesia
}

\begin{abstract}
Abstrak
Latar belakang Scabies adalah penyakit kulit menular disebabkan oleh tungau scarcoptes scabiei varian huminus. Ditandai dengan rasa gatal terutama pada malam hari. Scabies mudah menular melalui kontak langsung maupun tidak langsung. Penyakit scabies umunya ditemukan pada lingkungan kepadatan penghuni tinggi seperti penjara, panti asuhan, dan pondok pesantren. Scabies dapat disebabkan oleh sanitasi lingkungan dan perilaku yang kurang baik. Tujuan penelitian untuk menganalisis hubungan sanitasi asrama dan personal hygiene santri dengan kejadian scabies di Pondok Pesantren Al Ikhsan Desa Beji Kecamatan Kedungbanteng Kabupaten Banyamas. Jenis penelitian ini adalah observasional analitik dengan pendekatan cross sectional. Sampel dalam penelitian ini santri asrama putri Pondok Pesantren Al Ikhsan sebanyak 93 orang dengan metode proportional random sampling. Pengumpulan data dengan observasi, wawancara dan pengukuran. Analisis data menggunakan analisis univariat dan bivariate dengan uji statistik chi square $\left(X^{2}\right)$. Hasil penelitian terdapat 56 orang $(60,2 \%)$ positif scabies dan 37 orang $(39,8 \%)$ negatif scabies. Hasil uji statistik chi square $\left(X^{2}\right)$ analisis bivariate sanitasi asrama dengan kejadian scabies $(p=0,010, P R=4,477(C I=0,724-27.671))$ ada hubungan sanitasi asrama dengan kejadian scabies. Personal hygiene dengan kejadian scabies $(p=0,000, P R=2,611(C I=1,480-4,608))$ ada hubungan personal hygiene santri dengan kejadian scabies. Kesimpulan penelitian adalah ada hubungan sanitasi asrama dan personal hygiene dengan kejadian scabies di Pondok Pesantren Al Ikhsan. Disarankan untuk pengelola pondok pesantren untuk memperbaki kondisi sanitasi asrama dan memantau kesehatan santri, untuk santri sebaiknya memperhatikan kebersihan diri dan kesehatan, untuk dinas kesehatan membantu menangani masalah scabies di pondok pesantren.
\end{abstract}

Kata kunci $\quad$ : Sanitasi; Personal hygiene; Scabies; Pondok Pesantren

\begin{abstract}
[Background Scabies is a contagious skin disease that caused by the scarcoptes scabiei mite varientas huminus. Marked with a itching complaints especially at night. Scabies is a easily transmitted with direct or indirect contact. Scabies disease is commonly found in environments with high density inhabitants such as, prisons, orphanages, and boarding school. Scabies can be caused by environment sanitation conditions and unfavorable behavior. The research objective was analyze the correlation between dormitory sanitation and personal hygiene santri with incidence of scabies in the Al Ikhsan Beji Sub-District Kedungbanteng District Banyumas Regency. The research design used was observational analytic with cross sectional approach. The research sample was the santri in female dormitory boarding school Al Ikhsan as many 93 people with sampling method used as proportional random sampling. Data collection with observational, interview, and measurement. Data analysis using univariate analysis and bivariate analysis with chi square $\left(X^{2}\right)$ statistic test. The results of thus research were 56 people $(60,2 \%)$ positive scabies and 37 people $(39,8 \%)$ negative scabies. The result chi square $\left(X^{2}\right)$ statistic test that the bivariate analysis between dormitory sanitation with scabies incident ( $p=0,010, P R=4,477,(C I=0,724$ 27,671) it mean that there was significant correlation between dormitory with scabies incident. Personal hygiene student with scabies incident $(p=0,000, P R=2,611,(C I=1,480-4,608))$ it mean that there was significant correlation between personal hygiene student with scabies incident. The conclusion drawn that
\end{abstract}


there is significant correlation between dorminitiry sanitation and personal hygiene student with scabies incident in boarding school Al Ikhsan. Recommend for manager boarding school to improving sanitary conditions of the dormitory and monitor health student. For student should pay attention to personal hygiene and health, and for Dinas Kesehatan help handle the scabies problem in boarding school.

Key words $\quad$ : Sanitation; Personal hygiene; Scabies; boarding school

\section{Pendahuluan}

Penyakit scabies adalah penyakit menular yang disebabkan oleh sarcoptes scabiei varian homini. Penularannya terjadi secara kontak langsung maupun secara tidak langsung. Penyakit kulit ini ditandai dengan keluhan gatal. Penyakit Scabies dapat mengenai semua ras dan golongan di seluruh dunia. Banyak dijumpai pada anak dan orang dewasa muda, insidennya sama terjadi pada pria dan wanita (Harahap,2000).

World health Organization (WHO) menyatakan angka kejadian scabies pada tahun 2014 sebanyak 130 juta orang di dunia. Prevalensi penyakit scabies di Indonesia menurut Depkes RI berdasarkan data dari puskesmas seluruh Indonesia tahun 2008 mencapai 5,8\% sampai 12,95\% dan data prevalensi penyakit scabies di Indonesia menduduki urutan ketiga dari 12 penyakit kulit tersering. prevalensi penyakit scabies yang tinggi umunya ditemukan di lingkungan dengan kepadatan penghuni dan kontak interpersonal tinggi seperti penjara, panti asuhan, dan pondok pesantren (Ratnasari, 2014).

Faktor yang berperan dalam tingginya prevalensi penyakit scabies di negara berkembang terkait dengan kemiskinan yang berkaitan dengan rendahnya tingkat kebersihan, akses air yang sulit, personal hygiene dan kepadatan hunian. Tingginya kepadatan hunian dan interaksi atau kontak fisik dengan individu memudahkan transmisi dan infeksi tungau scabies (Harahap,2000).

Personal hygiene adalah upaya untuk memelihara hidup sehat berupa perilaku menjaga kebersihan pribadi. Personal hygiene meliputi perilaku mandi, perilaku berpakaian, perilaku mencuci tangan, dan perilaku tidur.

\footnotetext{
*) E-mail: trinova102@gmail.com

**) E-mail: lagionoabdulwahid@yahoo.co.id

${ }^{* * *}$ E-mail: budut17@yahoo.co.id
}

Hal lain yang menjadi faktor-faktor terjadinya penyakit skabies yaitu sanitasi lingkungan. Sanitasi lingkungan merupakan usaha kesehatan masyarakat untuk menjaga dan mengawasi faktor lingkungan yang dapat mempengaruhi derajat kesehatan.

Hasil penelitian yang dilakukan oleh Isa M., (2005), Pondok Pesantren di Lamongan, hasil pemeriksaan fisik kulit terhadap 338 orang santri Pondok pesantren menunjukkan bahwa prevalensi penyakit Scabies mencapai 64,20\%. Hasil penelitian menunjukkan bahwa prevalensi penyakit Scabies dikalangan para santri pondok pesantren di Kabupaten Lamongan juga dipengaruhi oleh sanitasi pondok pesantren yang masih kurang baik dan personal hygiene santri yang kurang baik.

Berdasarkan survei pendahuluan dilakukan pada pondok pesantren Al Iksan terdapat asrama putra dan asrama putri dengan jumlah santri sekitar 270 santri dari wawancara dengan pengurus santriwati di pondok pesantren Al Ikhsan Beji diperoleh bahwa penyakit kulit merupakan masalah kesehatan yang sering diderita oleh para santriwati. Belum adanya POSKESTREN (Pos Kesehatan Pesantren) di pondok pesantren Al Ikhsan sehingga tidak ada data kejadian scabies yang terjadi pada santri. Dari hasil wawancara yang dilakukan dengan santri pada 6 santri yang tinggal di asrama putri Pondok Pesantren Al Ikhsan diperoleh 3 dari 6 santri mengatakan pernah menderita penyakit kulit. Keluhan penyakit kulit pada santri berupa gatalgatal disertai bentol-bentol dipermukaan kulit pada tangan dan kaki.

Kondisi sanitasi asrama masih kurang baik, dapat dilihat dari kepadatan hunian yang tinggi, kamar dengan ukuran 4 x 4 m digunakan untuk 915 santri. Selain itu personal hygiene santri kurang baik seperti menggantung baju kotor di kamar, menjemur pakaian dan handuk tidak langsung terkena sinar matahari, dan kebiasan santri saling bertukar alat solat dan pakaian. Hal ini dapat menyebabkan penularan penyakit scabies. Sumber air yang digunakan di asrama berasal dari sumur gali yang jumlahnya cukup untuk memenuhi kebutuhan air santri. Tetapi pada kamar mandi masih menggunakan bak mandi untuk 
penampungan airnya, karena air dalam bak mand dapat terkontaminasi tungau dari penderita scabies. Sehingga hal tersebut dapat menjadi faktor risiko penularan scabies.

Kondisi Pondok Pesantren Al Ikhsan yang demikian, maka memungkinkan terjadinya penularan penyakit Scabies diantara para santri.

Tujuan penelitian ini adalah untuk menganalisis hubungan sanitasi asrama dan personal hygiene santri dengan kejadian scabies di Pondok Pesantren Al Ikhsan Desa Beji Kecamatan Kedungbanteng Kabupaten Banyamas Tahun 2018.

\section{METODE PENELITIAN}

Penelian ini menggunakan desain penelitian observasional analitik dengan pendekatan cross sectional untuk mempelajari hubungan antara sanitasi asrama dan personal hygiene santri di pondok pesantren Al Ikhsan Desa Beji. Populasi dalam penelitian ini adalah santri yang tinggal di asrama putri pondok pesantren Al Ikhsan yaitu 140 orang. besar sampel pada penelitian ini adalah santri putri yang tinggal di asrama putri pondok pesantren Al Ikhsan sebanyak 93 orang. Pemilihan subjek penelitian dilakukan dengan cara proporsional random sampling. Pengumpulan data dengan observasi, wawancara dan pengukuran. Analisis data menggunakan analisis univariat dan bivariate dengan uji statistik chi square $\left(\mathrm{X}^{2}\right)$.

\section{HASIL DAN PEMBAHASAN}

\section{Karakteristik Responden}

\section{a. Umur}

Tabel 1. Distribusi Frekuensi Responden Berdasarkan Umur di Pondok Pesantren Al Ikhsan Desa Beji Kecamatan Kedungbanteng Kabupaten Banyumas Tahun 2018

\begin{tabular}{|c|c|c|c|c|c|c|}
\hline \multirow{2}{*}{$\begin{array}{c}\text { Ketegori } \\
\text { Umur } \\
\text { (tahun) }\end{array}$} & \multicolumn{2}{|c|}{$\begin{array}{l}\text { Positif } \\
\text { scabies }\end{array}$} & \multicolumn{2}{|c|}{$\begin{array}{c}\text { Negative } \\
\text { scabies }\end{array}$} & \multicolumn{2}{|c|}{ Total } \\
\hline & $\mathrm{N}$ & $\%$ & $\mathrm{~N}$ & $\%$ & $\mathrm{~N}$ & $\%$ \\
\hline $12-14$ & 37 & 39,8 & 11 & 11,8 & 48 & 51,6 \\
\hline $15-17$ & 19 & 20,4 & 20 & 21,5 & 39 & 41,9 \\
\hline $18-20$ & 0 & 0,0 & 6 & 6,5 & 6 & 6,5 \\
\hline Jumlah & 56 & 60,2 & 37 & 39,8 & 93 & 100,0 \\
\hline
\end{tabular}

Berdasarkan tabel 1 dapat diketahui bahwa dari 93 orang responden sebagian besar responden

yaitu pada kategori umur 12-14 tahun sebanyak 48 orang $(51,6 \%)$ dengan santri yang positif scabies 37 orang $(39,8 \%)$ dan santri yang negative scabies 11 orang $(11,8 \%)$.
Usia seseorang demikian besarnya dalam mempengaruhi pengetahuan, sikap dan perilaku. Menurut Notonegoro (2003), umur mempengaruhi terhadap daya tangkap dan pola pikir seseorang, semakin bertambah umur akan semakin berkembang pula daya tangkap dan pola pikirnya sehingga pengetahuan yang diperoleh semakin banyak. Di beberapa Negara yang sedang berkembang prevalensi scabies cenderung tinggi pada anak anak serta remaja (Handoko, 2005).

\section{b. Tingkat pendidikan}

Tabel 2. Distribusi Frekuensi Responden Berdasarkan Tingkat Pendidikan di Pondok Pesantren Al Ikhsan Desa Beji Kecamatan Kedungbanteng Kabupaten Banyumas Tahun 2018.

\begin{tabular}{lcccrrr}
\hline \multirow{1}{*}{$\begin{array}{c}\text { Tingkat } \\
\text { Pendidikan }\end{array}$} & \multicolumn{2}{c}{$\begin{array}{c}\text { Positif } \\
\text { Scabies }\end{array}$} & \multicolumn{2}{c}{$\begin{array}{c}\text { Negatif } \\
\text { Scabies }\end{array}$} & \multicolumn{2}{c}{ Total (\%) } \\
\cline { 2 - 7 } & $\mathrm{N}$ & $\%$ & $\mathrm{~N}$ & $\%$ & $\mathrm{~N}$ & $\%$ \\
\hline SMP & 41 & 44,1 & 15 & 16,1 & 56 & 60,2 \\
SMA & 15 & 16,1 & 16 & 17,2 & 31 & 33,3 \\
$\begin{array}{l}\text { Perguruan } \\
\text { tinggi }\end{array}$ & 0 & 0,0 & 6 & 6,5 & 6 & 6,5 \\
\hline Jumlah & 56 & 60,2 & 37 & 39,8 & 93 & 100,0 \\
\end{tabular}

Berdasarkan tabel 2 diatas dapat diketahui bahwa dari 93 orang responden, pada penelitian ini responden yang paling banyak ada pada tingkat pendidkan SMP yaitu sebanyak 56 orang $(60,2 \%)$ dengan santri yang positif scabies 41 orang $(44,1 \%)$ dan santri yang negatif scabies 15 orang $(16,1 \%)$.

Menurut Notoatodjo (2003), tingkat pendidikan seseorang dapat meningkatkan pengetahuan tentang kesehatan. Semakin tinggi tingkat pendidikan seseorang semakin mereka tahu bagaimana cara pencegahan dan penularan penyakit. Orang yang berpendidikan rendah memiliki kesadaran rendah mengenai pengetahuan yang dapat berperan dalam penularan penyakit dan pengetahuan akan membangun sikap atau prilaku yang lebih baik. Hasil penelitian Ratnasari (2004), didapatkan bahwa prevalensi scabies lebih rendah pada tingkat pendidikan tsanawiyah.

\section{Analisis Univariat}

\section{a. Sanitasi Asrama}

Tabel 3. Hasil Inspeksi Sanitasi Asrama Di Pondok Pesantren Al Ikhsan Desa Beji Kecamatan Kedungbanteng Kabupaten Banyumas Tahun 2018 


\begin{tabular}{lcc}
\hline Sanitasi Asrama & $\begin{array}{c}\text { Jumlah } \\
\text { (kamar) }\end{array}$ & $\%$ \\
\hline Memenuhi Syarat & 1 & 7,7 \\
$\begin{array}{l}\text { Tidak Memenuhi } \\
\text { Syarat }\end{array}$ & 12 & 92,3 \\
\hline \multicolumn{1}{c}{ Total } & 13 & 100,0 \\
\hline
\end{tabular}

Berdasarkan tabel 3 dapat diketahui hasil inspeksi sanitasi asrama, dari 13 kamar yang ada di asrama putri Pondok Pesantren Al Ikhsan, yang memiliki kondisi sanitasi asrama yang memenuhi syarat yaitu sebanyak 1 kamar $(7,7 \%)$. Untuk kondisi sanitasi asrama santri yang tidak memenuhi syarat yaitu sebnayak 12 kamar $(92,3 \%)$.

Sanitasi ditujukan untuk meningkatkan dan mempertahankan standar kondisi lingkungan yang dapat mempengaruhi kesejahteraan hidup manusia (Notoadmojo, 2003)

Faktor yang berperan pada tingginya prevalensi skabies di Negara berkembang terkait dengan kemiskinan yang diasosiasikan dengan rendahnya tingkat kebersihan, akses air yang sulit, dan kepadatan hunian. Tingginya kepadatan hunian dan interaksi atau kontak fisik antar individu memudahkan perpindahan tungau skabies. Oleh karena itu, prevalensi skabies yang tinggi umumnya ditemukan di lingkungan dengan kepadatan penghuni dan kontak interpersonal tinggi seperti penjara, panti asuhan, dan pondok pesantren (Ratnasari, 2014).

\section{b. Personal Hygiene}

Tabel 4. Hasil kuesioner personal hygiene santri putri di asrama putri Pondok Pesantren Al Ikhsan Desa Beji Kecamatan Kedungbanteng Kabupaten Banyumas Tahun 2018

\begin{tabular}{|c|c|c|}
\hline Personal hygiene & $\begin{array}{l}\text { Jumlah } \\
\text { (orang) }\end{array}$ & $\%$ \\
\hline Memenuhi Syarat & 31 & 33,3 \\
\hline Tidak Memenuhi Syarat & 62 & 66,7 \\
\hline Total & 93 & 100,0 \\
\hline \multicolumn{3}{|c|}{$\begin{array}{l}\text { Berdasarkan tabel } 4 \text { dapat diketahui dari } 93 \\
\text { responden responden, yang memiliki personal } \\
\text { hygiene yang tidak memenuhi syarat adalah } 62 \\
\text { orang }(66,7 \%) \text {. Sedangkan responden yang } \\
\text { memiliki personal hygiene yang memenuhi syarat } \\
\text { yaitu sebanyak } 31 \text { orang }(33,3 \%) \text {. } \\
\text { Personal hygiene merupakan faktor penting } \\
\text { alam usaha pemeliharaan kesehatan, agar kita } \\
\text { elalu dapat hidup sehat. Seseorang dikatakan } \\
\text { hemiliki kebersihan diri baik apabila, orang } \\
\text { ersebut dapat menjaga kebersihan tubuhnya yang }\end{array}$} \\
\hline
\end{tabular}

meliputi kebersihan kulit, tangan, kuku, dan kebersihan genitalia (Rosmalia, 2012).

Tungau scarcoptes scabiei yang ada pada tubug penderita akan lebih mudah menginfeksi individu dengan personal hygiene perorangan yang kurang baik dan sebaliknya lebih sukar menginfestasi individu dengan personal hygiene yang baik karena tungau dapat dihilangkan dengan mandi dan mencuci rambut (keramas) yang teratur, pakaian dan handuk yang sering dicuci dan kebersihan alas tidur (Isa Ma'aruf, 2005).

\section{c. Kejadian Scabies}

Gambar 1. Kejadian Penyakit Scabies di Pondok Pesantren Al Ikhsan Desa Beji Kecamatan Kedungbanteng Kabupaten Banyumas Tahun 2018

Berdasarkan gambar 1. dapat diketahui dari

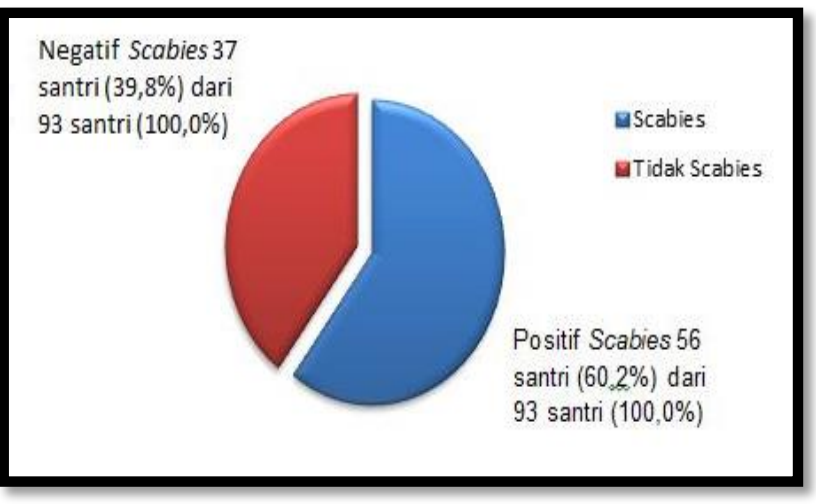

93 orang (100\%) yang menjadi responden terdapat 56 orang $(60,2 \%)$ yang positif scabies dan ada 37 orang $(39,8 \%)$ yang negatif scabies. Santri yang mengalami scabies tersebar di seluruh kamar santri.

Penyakit scabies sangat mudah menular karena dengan penularanya secara kontak langsung, maka melakukan kontak langsung dengan penderita dapat terjadi proses penularan. Hal ini yang menyebabkan penyakit scabies dengan prevalensi yang tinggi sering kali ditemukan di pondok pesantren mengingat kondisi asrama pada pondok pesantren yang dihuni oleh banyak individu sehingga kesempatan untuk terjadinya penularan penyakit scabies menjadi tinggi. Meskipun skabies tidak berdampak pada angka kematian akan tetapi penyakit ini dapat mengganggu kenyaman dan konsentrasi belajar para santri.

\section{d. Suhu Ruangan}

Tabel 5. Hasil Pengukuran Suhu Ruangan di Asrama Putri Pondok Pesantren Al Ikhsan Desa Beji Kecamatan Kedungbanteng Kabupaten Banyumas Tahun 2018 


\begin{tabular}{ccc}
\hline \multicolumn{1}{c}{ Suhu ruangan } & $\begin{array}{c}\text { Jumlah } \\
\text { (kamar) }\end{array}$ & $\%$ \\
\hline Memenuhi Syarat & 2 & 15,3 \\
Tidak Memenuhi & 11 & 84,6 \\
Syarat & 13 & 100,0 \\
\hline \multicolumn{1}{c}{ Total } &
\end{tabular}

Berdasarkan tabel 5. diketahui bahwa dari 13 kamar di asrama putri Pondok Pesantren Al Ikhsan yang kondisi suhu ruangan memenuhi syarat sebanyak 2 kamar (15,3\%), sedangkan yang tidak memenuhi syarat yaitu sebanyak 12 kamar $(84,6 \%)$.

Persyaratan untuk suhu ruangan menurut Kepmenkes RI No 829/MENKES/SK/VI/1999 tentang persyaratan perumahan adalah suhu udara yang ditentukan yaitu berkisar $18^{\circ} \mathrm{C}$ sampai $30^{\circ} \mathrm{C}$.

Dalam penelitian Windi (2014) yang menyebutkan bahwa suhu merupakan faktor risiko bagi terjadinya scabies. Kerena tungau scarcoptes scabiei sangat peka terhadap lingkungan. Suhu ruangan juga mempengaruhi kelembaban udara dan kenyamanan seseorang tinggal pada suatu tempat. Untuk itu perlu menjaga kondisi suhu ruangan agar selalu dalam kondisi baik.

\section{e. Kelembaban Ruangan}

Tabel 6. Hasil Pengukuran kelembaban Ruangan di Asrama Putri Pondok Pesantren Al Ikhsan Desa Beji Kecamatan Kedungbanteng Kabupaten Banyumas Tahun 2018

\begin{tabular}{lcc}
\hline Kelembaban ruangan & $\begin{array}{c}\text { Jumlah } \\
\text { (kamar) }\end{array}$ & $\%$ \\
\hline Memenuhi Syarat & 7 & 53,8 \\
$\begin{array}{l}\text { Tidak Memenuhi } \\
\text { Syarat }\end{array}$ & 6 & 46,2 \\
\hline \multicolumn{1}{c}{ Total } & 13 & 100,0 \\
\hline
\end{tabular}

Berdasarkan tabel 6. diketahui bahwa dari 13 kamar di asrama putri Pondok Pesantren Al Ikhsan yang memiliki kondisi kelembaban ruangan memenuhi syarat sebanyak 7 kamar (53,8\%), sedangkan yang tidak memenuhi syarat yaitu sebanyak 6 kamar $(46,2 \%)$.

Persyaratan untuk kelembaban ruangan menurut Kepmenkes RI No 829/MENKES/SK/VI/1999 tentang persyaratan perumahan, persyaratan untuk kelembaban ruangan yang ditentukan yaitu berkisar $40 \%$ sampai $70 \%$. Pada kondisi lingkungan yang kering tungau sarcoptes scabiei hanya bertahan hidup 2-3 hari dan menetas sampai sampai 6 hari, sedangkan pada kondisi lingkungan yang lembab tungau sarcoptes scabiei dapat bertahan hidup hingga 6 minggu (Windi, 2014). Pada kamar santri yang memiliki kelambaban yang tidak memenuhi syarat menjadi peluang bagi tungau untuk dapat bertahan hidup dan berkembangbiak, sehingga peluang untuk terjadinya penyakit scabies pada santri dalam kamar tersebut semakin meningkat. Sehingga semakin buruknya kelembaban suatu ruangan maka akan berpengaruh terhadap peningkatan kejadian penyakit scabies.

\section{f. Kepadatan Hunian}

Tabel 7. Hasil Pengukuran kepadatan hunian di Asrama putri Pondok Pesantren Al Ikhsan Desa Beji Kecamatan Kedungbanteng Kabupaten Banyumas Tahun 2018

Berdasarkan tabel 7 diketahui bahwa kondisi kepadatan hunian di asrama putri Pondok Pesantren Al Ikhsan yang tidak memenuhi syarat sebanyak 13 kamar (100,0\%), pengukuran kepadatan hunian yang dilakukan menunjukan kepadatan hunian masih tinggi di seluruh kamar santri.

Persyaratan tentang kepadata hunian kamar

\begin{tabular}{ccc} 
menurut & Kepmenkes & RI \\
\hline Kepadatan Hunian & $\begin{array}{c}\text { Jumlah } \\
\text { (kamar) }\end{array}$ & $\%$ \\
\hline Memenuhi Syarat & 0 & 0,0 \\
$\begin{array}{l}\text { Tidak Memenuhi } \\
\text { Syarat }\end{array}$ & 13 & 100,0 \\
\hline \multicolumn{1}{c}{ Total } & 13 & 100,0 \\
\hline
\end{tabular}

829/MENKES/SK/VI/1999 tentang persyaratan perumahan, persyaratan untuk kepadatan hunian kamar adalah kepadatan hunian kamar tidur yang ditentukan yaitu berkisar $8 \mathrm{~m}^{2}$ tidak lebih dihuni oleh dua orang.

Jumlah penghuni pada suatu ruangan yang melebihi persyaratan dan kapasitas akan meningkatkan suhu ruangan menjadi panas yang disebabkan oleh keluarnya panas tubuh juga akan meningkatkan kelembaban akibat adanya uap air dari pernafasan maupun penguapan cairan tubuh dari kulit. Sehingga menyebabkan kondisi suatu ruangan kurang nyaman (Mushalina Lathifa,2014).

Luas bangunan yang tidak sebanding dengan jumlah penghuni akan menyebabkan kepadatan hunian. Hal ini menyebabkan kondisi yang tidak sehat sebab disamping kurangnya konsumsi oksigen setiap individu di tempat tersebut juga dapat mengakibatkan penularan penyakit scabies antar individu semakin tinggi. Tingginya kepadatan hunian dan interaksi atau kontak fisik antara individu menjadi tinggi memudahkan penularan penyakit scabies antar individu, oleh karena itu prevalensi scabies yang tinggi umumnya ditemukan di lingkungan dengan kepadatan hunian dan kontak 
interpersonal tinggi seperti di penjara, panti asuhan, pondok pesantren (Ratnasari,2014).

\section{g. Kualitas Air}

Tabel 8. Kualitas Air Berdasarkan Kualitas fisik air, $\mathrm{pH}$ Air, dan Suhu Air di Pondok Pesantren Al Ikhsan Desa Beji Kecamatan Kedungbanteng Kabupaten Banyumas Tahun 2018

\begin{tabular}{cllcc}
\hline $\begin{array}{c}\text { Kran } \\
\text { ke }\end{array}$ & Sumber air & \multicolumn{1}{c}{ Kualitas fisik } & $\begin{array}{c}\text { pH } \\
\text { Air }\end{array}$ & $\begin{array}{c}\text { Suhu } \\
\left({ }^{\circ} \mathrm{C}\right)\end{array}$ \\
\hline 1 & Sumur Gali & Memenuhi syarat & 7 & 28 \\
2 & Sumur Gali & Memenuhi syarat & 7 & 28 \\
3 & Sumur Gali & Memenuhi syarat & 7 & 29 \\
4 & Air sungai & Tidak memenuhi & 6 & 29 \\
& banjaran & syarat & & \\
\hline
\end{tabular}

Berdasarkan tabel 8 hasil inspeksi kualitas air bersih yang ada di asrama putri Pondok Pesantren Al Ikhsan menunjukan bahwa air bersih yang disediakan berasal dari 2 sumber yaitu dari air sumur gali dan air sungai banjaran. Hasil inspeksi kualitas fisik air yang bersumber dari sungai tidak memenuhi syarat karena kondisi air tidak berbau, tetapi air berasa dan warnanya keruh kecoklatan. Untuk air dari sumur kualitasnya memenuhi syarat yaitu tidak berasa, tidak berwarna, dan tidak berbau. Dan untuk pengukuran $\mathrm{pH}$ air dan suhu air diperoleh hasil air yang berasal dari sumur niali $\mathrm{pH}$ air adalah 7 dengan suhu air $28-29{ }^{\circ} \mathrm{C}$, sedangkan air yang berasal dari sungai nilai $\mathrm{pH}$ air adalah 6 dengan suhu air $29^{\circ} \mathrm{C}$.

Air dapat menjadi salah satu faktor penyakit scabies. Walaupun kualitas air secara fisik baik tapi belum tentu mikroorganisme yang ada pada air tersebut tidak ada karena sarana air yang tidak dikelola dengan baik dapat menyebabkan suatu penyakit. Air yang disediakan di asrama putri Pondok Pesantren Al Ikhsan di distribusikan pada 4 bak, untuk 1 bak dibagi untuk 2 -5 kamar mandi. Masih menggunakan bak sebagai sarana air bersih. Hal ini Secara tidak langsung dapat menjadi sumber penularan penyakit scabies. Karena penderita scabies dapat bersentuhan langsung dengan air yang ada dibak sehingga air dapat terkontaminasi oleh tungau scarcoptes scabiei.

\section{h. Kuantitas Air}

Tabel 9. Hasil Pengukuran Debit Air di Pondok Pesantren Al Ikhsan Desa Beji Kecamatan Kedungbanteng Kabupaten Banyumas tahun 2018
Berdasarkan tabel 9 hasil pengukuran debit air, total debit air dari semua kran adalah 0,33 liter/detik. Sehingga dalam satu hari jumlah air yang disediakan di asrama putri Pondok Pesantren Al Ikhsan Desa Beji yaitu 28.512 liter/hari. Sedangkan kebutuhan air bersih dalam sehari di asrama putri pondok pesantren Al Ikhsan adalah 16.800 liter/hari.

\begin{tabular}{|c|c|}
\hline Kran air ke & Debit (L/detik) \\
\hline 1 & 0,07 \\
\hline 2 & 0,06 \\
\hline 3 & 0,07 \\
\hline 4 & 0,10 \\
\hline Total & 0,33 \\
\hline
\end{tabular}
memenuhi kebutuhn air bersih sehari-hari karena penyediaan air yang terbatas dapat memudahkan timbulnya penyakit. Pada kasus scabies penyedian air bersih adalah kunci utama yang berperan dalam penluaran scabies pada santri pondok pesantren, karena penyakit scabies termasuk penyakit yang berkaitan dengan kekurangan air bersih (water wash disease) yang digunakan kebutuhan air bersih sehari-hari

\section{Analisis Bivariat}

\section{a. Hubungan Sanitasi Asrama Dengan Kejadian Scabies}

Tabel 10. Tabel Silang Hubungan Antara Sanitasi Asrama Dengan Kejadian Scabies di Pondok Pesantren Al Ikhsan Desa Beji Kecamatan Kedungbanteng Kabupaten Banyumas Tahun 2018

\begin{tabular}{lcccccc}
\hline \multirow{2}{*}{$\begin{array}{c}\text { Sanitasi } \\
\text { asrama }\end{array}$} & \multicolumn{2}{c}{ Scabies } & \multicolumn{2}{c}{$\begin{array}{c}\text { Tidak } \\
\text { scabies }\end{array}$} & Total \\
\cline { 2 - 7 } & $\mathrm{N}$ & $\%$ & $\mathrm{~N}$ & $\%$ & $\mathrm{~N}$ & $\%$ \\
\hline $\begin{array}{l}\text { Tidak } \\
\text { memenuhi } \\
\text { syarat }\end{array}$ & 55 & 59,1 & 31 & 33,3 & 86 & 92,4 \\
$\begin{array}{l}\text { Memenuhi } \\
\text { syarat }\end{array}$ & 1 & 1,1 & 6 & 6,5 & 7 & 7,6 \\
\hline \multicolumn{1}{c}{ Total } & 56 & 60,2 & 37 & 39,8 & 93 & 100,0 \\
\hline$a=0,05 \quad p=0,010$ & $\mathrm{PR}=4.477$ & $\mathrm{CI}=(0,72427.671)$
\end{tabular}

Berdasarkan tabel 10 hasil uji chi square hubungan antara sanitasi asrama dengan kejadian scabies tingkat signifikan 5\% $(0,05)$ dan df sebesar 1 diperoleh nilai $\mathrm{x}^{2} \mathrm{p}=0,010$ karena $p$-value $0,010<$ 0,05 artinya ada hubungan antara sanitasi asrama dengan kejadian scabies di pondok pesantren $\mathrm{Al}$ Ikhsan Desa Beji Kecamatan Kedungbanteng Kabupaten Banyumas Tahun 2018. Hasil perhitungan di dapatkan nilai $\mathrm{PR}=4,477(95 \% \mathrm{Cl}$ : 0,724-27.671), dan menunjukan nilai $P R>1$ maka 
variabel sanitasi asrama merupakan faktor risiko penyebab terjadinya scabies. Besar faktor risiko terjadinya penyakit scabies pada santri yang tinggal di asrama dengan memiliki sanitasi asrama yang tidak memenuhi syarat yaitu 4 kali lebih besar terkena scabies dari pada santri yang tinggal di asrama dengan memiliki sanitasi asrama yang memenuhi syarat.

Hasil penelitian ini tidak sesuai dengan penelitian yang dilakukan yuni (2006) menunjukan bahwa kejadian scabies dan responden yang memiliki sanitasi lingkungan rumah tidak memenuhi syarat belum tentu berisiko terkena penyakit scabies. Dimungkinkan terdapat faktor lain yang berpengaruh terhadap penularan penyakit scabies seperti personal hygiene, kualitas air yang digunakan untuk kebutuhan sehari-hari, perilaku santri, dan kontak langsung dengan penderita.

Tetapi sesuai dengan hasil penelitian yang dilakukan oleh Elvi (2014), menunjukkan bahwa ada hubungan antara kondisi sanitasi asrama dengan kejadian scabies di Pondok Pesantren Darul Ma,Arif Kabupaten Sintang, nilai $P=0,006$ nilai $\mathrm{OR}=4,047$ artinya santri dengan sanitasi asrama kurang baik memiliki risiko terkena scabies 4 kali dibandingkan dengan sanitasi asrama yang baik.

\section{b. Hubungan Personal Hygiene Santri Dengan Kejadian Scabies}

Tabel 11. Hubungan Antara Personal Hygiene Santri Dengan Kejadian Scabies di Pondok Pesantren Al Ikhsan Desa Beji Kecamatan Kedungbanteng Kabupaten Banyumas Tahun 2018

\begin{tabular}{|c|c|c|c|c|c|c|}
\hline \multirow{2}{*}{$\begin{array}{c}\text { Personal } \\
\text { Hygiene } \\
\text { Santri }\end{array}$} & \multicolumn{2}{|c|}{ Scabies } & \multicolumn{2}{|c|}{$\begin{array}{c}\text { Tidak } \\
\text { Scabies }\end{array}$} & \multicolumn{2}{|c|}{ Total } \\
\hline & $\mathrm{N}$ & $\%$ & $\mathrm{~N}$ & $\%$ & $\mathrm{~N}$ & $\%$ \\
\hline $\begin{array}{l}\text { Tidak } \\
\text { memenuhi } \\
\text { syarat }\end{array}$ & 47 & 50,5 & 15 & 16,1 & 62 & 66,6 \\
\hline $\begin{array}{l}\text { Memenuhi } \\
\text { syarat }\end{array}$ & 9 & 9,7 & 22 & 23,7 & 31 & 33,4 \\
\hline Total & 56 & 60,2 & 37 & 39,8 & 93 & 100 \\
\hline $\begin{array}{l}\qquad a=0,05 p= \\
\text { Berdas } \\
\text { uji chi squar } \\
\text { santri dengan } \\
(0,05) \text { dan df } \\
\text { karena } p \text {-valu } \\
\text { antara persor } \\
\text { scabies di Po } \\
\text { Kecamatan K } \\
\text { Tahun } 2018 . \\
\text { PR=2.611 }\end{array}$ & $\begin{array}{l}\text { adia } \\
\text { adia } \\
, 010 \\
h y g \\
\text { ok P } \\
\text { ungb } \\
\text { sil } \\
\mathrm{Cl} \text { : }\end{array}$ & $\begin{array}{l}\mathrm{R}=2 . \\
\text { el } 4.1 \\
\text { an an } \\
\text { cabie } \\
\text { dipe } \\
0,05 \\
\text { ne sa } \\
\text { antren } \\
\text { teng } \\
\text { rhitun } \\
480-4\end{array}$ & $\begin{array}{l}\text { artin } \\
\text { al } \\
\text { tri } \\
\text { abu }\end{array}$ & $\begin{array}{l}\mathrm{I}=(1, \\
\text { t dike } \\
\text { ersonc } \\
\text { at sigi } \\
\text { ilai } \mathrm{x} \\
\text { a ada } \\
\text { lengan } \\
\text { chsan } \\
\text { aten }\end{array}$ & $\begin{array}{l}1 \mathrm{kan} \\
=0 \\
\text { abun } \\
\text { keja }\end{array}$ & \\
\hline
\end{tabular}

nilai PR > 1 maka variabel personal hygiene santri merupakan faktor risiko penyebab terjadinya scabies. Besar faktor risiko terjadinya penyakit scabies pada santri yang memiliki personal hygiene yang tidak memenuhi syarat yaitu 3 kali lebih besar terkena penyakit scabies dari pada santri yang memiliki personal hygiene yang memenuhi syarat.

Hal ini tidak sesuai dengan penelitian yang dilakukan Wijaya (2011) yang menyatakan bahwa tidak ada hubungan antara personal hygiene dengan kejadian scabies di Pondok Pesantren Al Makmur, karena ada faktor lain yang mempengaruhi timbulnya penyakit scabies yaitu faktor sanitasi lingkungan yang dapat meningkatkan kejadian scabies di pondok pesantren.

Namun penelitian ini sejalan dengan penelitian yang dilakukan Isa Ma'arif (2005), yang menyatakan bahwa sebagian besar santri yang mempunyai personal hygiene yang jelek menderita penyakit scabies sebanyak 73,70\%, sedangkan jika dilihat dari sub variabel personal hygiene terdapat hubungan yang signifikan antara kejadian penyakit scabies yaitu frekuensi mandi pakai sabun dan penggunaan tempat tidur.

\section{IV.SIMPULAN DAN SARAN Simpulan}

Dari penelitian ini dapat disimpulkan Kondisi sanitasi asrama di Pondok Pesantren Al Ikhsan Desa Beji terdapat 12 (92,3\%) kamar yang tidak memenuhi syarata, dan Kondisi personal hygiene santri Pondok Pesantren Al Ikhsan Desa Beji terdapat santri yang memiliki personal hygiene yang tidak memenuhi syarat adalah 62 orang $(66,7 \%)$. Sedangkan Kejadian penyakit scabies di Pondok Pesantren Al Ikhsan Desa Beji Kecamatan Kedungbanteng tahun 2018 adalah terdapat 56 orang $(60,2 \%)$ yang positif scabies dan 37 orang $(39,8 \%)$ yang negative scabies. Dari hasil uji statistik adalah terdapat hubungan antara sanitasi asrama dan personal hygiene saantri dengan kejadian scabies di Pondok Pesantren Al Ikhsan Desa Beji Kecamatan Kedungbanteng Kabupaten Banyumas tahun 2018.

\section{Saran}

Sebaiknya untuk pengelola pondok pesantren memperhatikan dan memperbaiki kondisi sanitasi asrama yang masih kurang baik, membentuk POSKESTREN (Pos Kesehatan Pesantren) untuk memenuhi pelayanan kesehatan santri, dan menghimbau kepada santri untuk menjaga kebersihanlingkungan dan melakukan PHBS setiap hari. Selain itu perlu adanya penyuluhan terkait pencegahan penyakit scabies dan pentingnya PHBS untuk santri dan inspeksi sanitasi 
pondok pesantren dan pemeriksaan kualitas air bersih secara fisik kimia dan maupun biologi yang dilakukan oleh petugas kebersihan. Dan untuk santri sebaiknya menerapkan PHBS setiap hari.

\section{DAFTAR PUSTAKA}

Agsa Sajida, 2012, Hubungan Personal Hygiene Dan Sanitasi Lingkungan Dengan Keluhan Penyakit Kulit Di Kelurahan Denai Kecamatan Medan Denai Kota Medan Skripsi: Universitas Sumatra Utara.

Ahmad Muhakamurrohman, 2014, Pesantren: Santri Kiai, Dan Tradisi At Http://Ejournal.Iainpurwokerto.Ac.Id/Inde x.Php/Ibda/Article/Download. Diakses Pada Tanggal 28 Desember 2017.

Aris Santjaka, 2011, Statistik Untuk Penelitihan Kesehatan, Yogyakarta: Nuha Medika

Amajida, Fadila Saleha S, 2014, prevalensi scabies dan hubungan dengan jenis kelamin dan tingkat pendididkn santri pondok pesantren $x \quad$ Jakarta timur https://www.neliti.com/id/publications/59 576/prevalensi-scabies-dan-faktor-yangberhubungan-di-pesantren-x-jakarta-tim diakses pada tanggal 12 November 2017.

Benny Roland N, 2013,Karakteristik Penderita Scabies di RSUP H. Adam Malik Medan, Skripsi, Medan: Universitas Sumatrera Utara

Budiman, Hamida, M Faqih, 2015, Hubungan Kebersihan Perorangan Dan Kondisi Fisik Air Dengan Kejadian Scabies Di Desa Wombo Kecamatan Tanantovea Kabupaten Donggala, at Http://Juornal.Uin-

Alauddin.Ac.Id/Index.Php/Hygiene

Diakses Pada Tanggal 12 November 2017.

Chanifah Umi, 2013, Hubungan Sanitasi Asrama Dan Personal Hygiene Dengan Kejadian Scabies Di Pondok Pesantren Tahfidzul Qur'an (PPTQ) Al-Asy'ariyyah Wonosobo, Karya Tulis Ilmiah, Purwokerto: Poltekkes Semarang

Depkes RI, 2007, Pedoman Penyelenggaran Dan Pembinaan Pos Kesehatan Pesantren, Jakarta: Dirjen Bina Kesehatan Masyarakat.
Dwi Ari Budiarti,, 2012, Hubungan Antara Sanitasi Asrama, Pengetahuan Dan Personal Hygiene Santri Dengan Kejadian Scabies Di Pondok Pesantren Roudhotul qur'an Desa Sirau Kecaamatan Kemranjen Kabupaten Banyumas Kaya Tulis Ilmiah Purwokerto: Poltekkes Semarang.

Gabrela Bilova, 2016, Analisis Faktor Faktor Yang Mempengaruhi Pengeluaran Kesehatan Per Kapita Di Indonesia, Skripsi, Padang : Universitas Andalas.

Griana, 2013, Scaies : Penyebab, Penanggulangan Dan Pencegahan, El- Hayah Vol 4 No.1, at ejournal.uinmalang.ac.id/index.php/bio/article/view/2 619/4560 Universitas Islam Negeri Maulana Malik Ibrahin Malang, diakses pada tangaan 22 November 2018.

Harahab M, 2000, Ilmu Penyakit Kulit, Jakarta: Hipokrates

Hanna Mutiara, Firza Syailindra, 2016, Scabies. Diunduh pada http://juke.kedokteran.unila.ac.id/index.ph p/majority/article/download.html. Diunduh pada tanggal 8 januari 2018

Isa M, Soedjajadi, Hari B.N, 2005 Faktor Sanitasi Lingkungan Yang Berperan Terhadap Prevalensi Penyakit Scabies Studi Pada Santri Di Pondok Pesantren Kabupaten Lamongan, Jurnal Kesehatan Lingkungan, Vol 2, No.1. at journal.unair.ac.id/filter/PDF/KESLING2-1.pdf Diakses Tanggal 12 November 2017.

Kepmenkes RI, 2013, Peraturan Menteri Kesehatan RI Nomor 1 Tahun 2013 Tentang Pedoman Penyelenggaraan Dan Pembinaan Pos Kesehatan Pesantren (POSKESTREN), Jakarta: Pusat Promosi Kesehatan.

,2009, Undang-Undang Republik Indonesia Nomor 36 Tahun 2009 Tentang Kesehatan, Jakarta : Kemenkes RI.

Notoadmojo,2003, Pendidikan Dan Perilaku Sehat, Rineka Cipta: Jakarta.

Riris Nur, 2010, Hubungan Faktor Pengetahuan Dan Prilaku Dengan Kejadian Scabies Di Pondok Pesantren Al Muayyad Surakarta, 
skripsi : Universitas Muhammadiyah Surakarta.

Risak Rinaldi, La Dupai, 2015, Pengaruh Permainan Mencocokan Tulisan Dengan Gambar Berserta Video Terhadap Peningkatan Pengetahuan Sikap Dan Perilaku Mengenai Penyakit Scabies Pada Siswa Kelas VII Dan VIII Pondok Pesantren Darul Mukhlisin Kota Kendari, at

Https://Www.Neliti.Com/Id/Journal/Jimke smas Diakses Pada Tanggal 15 November 2017.

Ratnasari, A.F. \& Sungkar, S. 2014, Prevalensi scabies dan faktor-faktor yang berhubungan di Pesantren X, Jakarta Timur.

Dari http://journal.ui.ac.id/index.php/eJKI/artic le/viewFile/3177/2470. Diunduh tanggal 20 November 2017.

Sabit, 2015, Tinjauan Dan Perilaku Hiduo Bersih Dan Sehat Santri Pondok Pesantren Darussa'adah Desa Kritig Kecamatan Petanahan Kabupaten Kebumen, Skripsi, Purwokerto: Poltekkes Semarang.
Soedarto 2003, Zoonosis Kedokteran, Surabaya: Airlangga University Press.

Syahri Romadlon, 2016 Hubungan Praktik Personal Hygiene Dan Kondidsi Sanitasi Lingkungan Dengan Kejadian Scabies Di Pondok Pesantren Roudhotu Tholibin Sirau Kecamatan Kemranjen Kabupaten Banyumas, Skripsi, Purwokerto: Poltekkes Semarang.

Tri Cahyono, 2017, Penyehatan Udara, Yogyakarta: penerbit Andi

Wartonah, 2003, Kebutuhan Dasar Manusia Dan Proses Keperawatan, Jakarta: Salemba Medika

Yuni, W. 2006, Hubungan sanitasi lingkungan dan higiene perorangan dengan penyakit skabies di desa genting kecamatan jambu, kabupaten semarang, otomasi.unnes.ac.id. Diunduh tanggal 27 maret 2018

Zalkoni Akhsin, 2010, Parasitologi, Yogyakarta: Nuha Medika 